\title{
Renewal of Crop Index-Based Insurance Uptake: Evidence from Senegal
}

\author{
Mame Mor Anta Syll1,2 \\ ${ }^{1}$ University Gaston Berger (UGB), Saint-Louis, Senegal \\ ${ }^{2}$ Initiative Prospective Agricole et Rurale (IPAR, Think Tank), Dakar, Senegal \\ Email: mamemorantasyll@gmail.com
}

How to cite this paper: Syll, M. M. A (2021). Renewal of Crop Index-Based Insurance Uptake: Evidence from Senegal. Open Journal of Social Sciences, 9, 1-8. https://doi.org/10.4236/jss.2021.911001

Received: September 21, 2021

Accepted: November 1, 2021

Published: November 4, 2021

Copyright (c) 2021 by author(s) and Scientific Research Publishing Inc. This work is licensed under the Creative Commons Attribution International License (CC BY 4.0).

http://creativecommons.org/licenses/by/4.0/

\begin{abstract}
In this work, we estimate the determinants of the renewal of weather index-based insurance contracts by Senegalese farmers who practiced rain-fed agriculture in the Senegalese groundnut during the years 2014, 2015 and 2016. Based on data on 3698 producers to whom weather index-based insurance bundled with an agricultural loan was proposed, we conducted a survival analysis using an Andersen-Gill cox regression to identify the drivers of the contract renewal. Our results show that difference in gender and amount of premiums paid do not explain contracts' renewal. However, cooperatives to whom farmers are affiliated, possibility to delay premium payment until the reimbursement of loans and whether payouts were triggered or not, were the core determinants of renewal after the first year of purchase.
\end{abstract}

\section{Keywords}

Renewal, Weather Index-Based Insurance, Survival Analysis, Determinants, Andersen-Gill Cox Regression

\section{Introduction}

The so-called "traditional" agricultural insurance, i.e. based on the observation and assessment of damage to crops, has existed since the 1930s in the United States. They have recently developed more specifically in the form of comprehensive insurance (hail, frost, and drought) and insurance against natural disasters. For many reasons, these insurances have only been adopted widely where they are heavily subsidized. For example, in the United States, the federal government pays about half of insurance premiums (Skees et al., 2006).

Weather derivatives are financial products, which allow certain companies to protect themselves against the vagaries of the climate. Agricultural insurance 
based on meteorological indices better known as weather index-based insurance (WII) make the link between the market of weather derivatives and the market of crop insurance, which makes it an interesting product for agriculture in developing countries. The principle of WII consists in compensating farmers if an index defined from meteorological variables passes a certain threshold, in exchange for an annual insurance premium (Chetaille \& Lagandré, 2010). Initiated by academic work (Halcrow, 1948; Dandekar, 1977), WIIs have been the subject of numerous pilot projects and large-scale development in a few countries (Carter et al., 2014).

The research question considered is the following: what are the drivers of the renewal of WII uptake by small farmers after a first purchase? Among the rare results that exist in the literature, it has been shown that deferred payment of premiums, automatic renewal, bundling with lead products, farmer's own receipt of insurance payouts, receipt of payouts by others in the farmer's social network and recent poor rain in the village could all positively influence renewal. Our work contributes to the literature on the renewal of crop insurance demand by showing that Cooperatives to whom farmers are affiliated, possibility to delay premium payment, and payouts are amongst the core determinants of renewal after a first purchase in the context of the Senegalese rain-fed agriculture.

\section{Literature}

Several studies have highlighted the low demand for microinsurance, particularly crop insurance (Cole et al., 2013; Gine \& Yang, 2008; Gine \& Yang, 2009), but few have looked at the determinants of the renewal of the contracts. The studies we have identified in the literature regarding the determinants of renewal can be organized into three main groups. Some results highlight the positive effect of delaying premium payments. Others revolve around the positive effect of automatic renewal with drawbacks when the product is bundled with a lead product that purchasers can drop when they are not interested in the mandatory insurance product. Finally, there is the effect of past shocks and indemnification or social network, which could also positively influence renewal.

a) Effects of delaying premium payment

In their study conducted in China, Chen et al. (2012) evaluated the effect of deferred premium payments for livestock (pork insurance). They offered to participants the possibility to delay premium payment by providing them credit checks that enable to purchase insurance with a possibility to pay the premiums at the moment of the sales of the animals. The authors found a higher increase of the purchases and renewals for the group of producers who benefited from the deferred premium payment option ( $11 \%$ increase) compared to $5 \%$ for producers who did not have the same possibility. Liu et al. (2013) confirmed the positive relation between delayed payment and demand as part of a randomized control trial in rural China where they found that insurance take-up is higher when farmers were given the option to pay at the end of the insured period. 
b) Possibility of automatic renewal

Cai et al. (2009) who showed that renewals are higher in this case compared to a case where automatic renewal does not exist prove this. An alternative to automatic renewal that is still parented to it as it seeks to foster uptake is mandatory insurance when the product is bundled with a lead product such as credit though this approach does not guarantee the renewal of uptake (Banerjee, Duflo, \& Hornbeck, 2014). There is also the case of the health insurance system, when civil servants and formal workers' contributions are automatically renewed such as in the example of the National Health Insurance System in Ghana (Khalid \& Serieux, 2018).

c) Past shocks and indemnification or social network

Literature results did not find a clear evidence showing that past shocks could increase future demand for crop insurance. Galarza \& Carter (2010) found that after a shock, farmers are not more likely to buy insurance as already experiencing past shocks make them believe that there is low chance for it to occur again and that the following seasons would be good. Stein (2011) explored how previous insurance payouts could affect future insurance purchasing decisions using data on three years of insurance purchasers from the Indian micro-finance institution BASIX. The author found that customers who received an insurance payout were more likely to repurchase in the following year as compared to customers who did not receive any insurance payments. In another study in Ghana, it has been shown that farmer's own receipt of insurance payouts, receipt of payouts by others in the farmer's social network and recent poor rain in the village could all positively influence renewal (Karlan et al., 2014).

\section{Data and Method}

We use a secondary database provided by the only agricultural insurer present in Senegal (CNAAS-“Compagnie Nationaled Assurance Agricole du Sénégal”). The dataset is composed of 3698 producers after clearance. These producers are located in the Senegalese groundnut basin where rain-fed agriculture is mainly practiced. The periods covered are the 2014, 2015 and 2016 agricultural seasons. During these three seasons, the WII product was available to farmers who were affiliated to the three main farmers' organisations RNCPS, CCPA and FEPROMAS in the districts of Ndoffane, Nioro, Kaffrine, and Koungheul in the groundnut basin.

The dataset provides annual information on farmers who purchase the WII for each season. Thus, the number of records for each individual depends on whether she has been insured or not in one of the three seasons considered. Besides, we considered two start times (first year of insurance) which are 2014 and 2015 as we could only observe the renewal for farmers who were insured during these two years. For farmers for whom the start time was 2016, it was not possible to observe the renewal. They were hence not considered in the analysis. The renewal variable could hence only take three values: 0 if the farmer was insured only once between the two starting years (2014 and 2015) and not insured in 2016; 1 if the farmer was insured two times during the three years, and 2 if the 
farmer was insured during each of the three years. From that, we can derive a dropout (failure variable) which will take the value 1 every time an individual decides not to renew its contract after either a first or second purchase. Table 1 below summarizes the detail on the purchase, renewal, and dropout for each season.

As the question, we are trying to answer is what proportion of farmers will renew their contracts after the first year of the purchase or in other words, what is the proportion of insurance contracts that will survive past the first year of coverage, we are in a context of survival data analysis. More specifically, it is a case of multiple failure-time data or multivariate survival data as the failure event, which is in our case the dropout of the insurance product, could be recurrent. We will therefore consider the counting process model of Anderson-Gill (Andersen \& Gill, 1982) to take into account the nature of the data (ordered failure events). An Andersen-Gill cox regression model will hence be considered to estimate the coefficients of the variables of interest in our estimation of the determinants of the renewal or dropout of the WII product. The predictors considered are described in Table 2 below.

Table 1. Purchase, renewal and dropout of WII per year.

\begin{tabular}{ccccccc}
\hline \multirow{2}{*}{ \#Purchase } & renewal & dropout & \multicolumn{5}{c}{ Year } \\
\cline { 4 - 7 } & & & $\mathbf{2 0 1 4}$ & $\mathbf{2 0 1 5}$ & $\mathbf{2 0 1 6}$ & Total \\
\hline 1 & 0 & 1 & 813 & 993 & 0 & 1806 \\
2 & 1 & 1 & 681 & 1112 & 591 & 2384 \\
3 & 2 & 0 & 700 & 700 & 700 & 2100 \\
& Total & & 2194 & 2805 & 1291 & 6290 \\
\hline
\end{tabular}

Source: Author.

Table 2. Description of the predictors considered in the estimation.

\begin{tabular}{cl}
\hline Variables & \multicolumn{1}{c}{ Description of the variables } \\
\hline Gender & $\begin{array}{l}\text { Reports the gender of the farmers: } 1=\text { women; } 2=\text { men } \\
\text { Premium }\end{array}$ \\
& $\begin{array}{l}\text { The amount of premium paid by the farmers for each year of } \\
\text { coverage. Mean premium = 7867 CFA (14 USD) } \\
\text { Spatial variable controlling for the geographical differences between } \\
\text { the insured production areas. As rainfall distribution can be different } \\
\text { from place to place, farmers are divided into four areas namely, the } \\
\text { district of Ndoffane, Kaffrine, Kaolack, and Nioro, using the location } \\
\text { of the weather stations of the Senegalese meteorological agency. }\end{array}$ \\
Cooperatives & $\begin{array}{l}\text { Cooperatives to which the farmers hold membership and through } \\
\text { which they have access to the insurance product. Three cooperatives } \\
\text { are considered. The CCPA, the RNCPS, and the FEPROMAS. }\end{array}$ \\
Delayed & $\begin{array}{l}\text { It determines whether the premium is paid at the moment of the } \\
\text { purchase of the insurance product or whether it is linked to the credit } \\
\text { and will be paid at the end of the season (after the marketing period) } \\
\text { at the time of the loan reimbursement. }\end{array}$
\end{tabular}

Source: Author. 


\section{Results and Discussion}

The Andersen-Gill cox regression model provides the results presented in Table 3 below. The direction of the relation between the predictors and the survival time is provided by the Hazard ratio (HR). We can remark that the gender predictor is not significant and whether a farmer is a man ( $81 \%$ in our sample) or woman (19\% in the sample) does not seem to make a difference for the renewal of the insurance contracts. The cost of the insurance product (premium) also is not significant and hence does not make a difference for the renewal of the contracts. Regarding the zones considered, a difference is observed only for farmers living in Ndoffane who present a $17 \%$ more chance to renew their contracts compared to farmers of Kaffrine. This could be explained by the fact that while all the four zones considered belong to the Senegalese groundnut basin and have quite similar agro-climatic characteristics, Ndoffane is mostly located in the north and is, therefore, the most exposed to the risk of drought linked to a rainfall deficit. The survival time of the contracts in the Nioro and Kougheul zones seems to be the same as the one in the Kaffrine zone. The "Cooperatives" predictor which considers the three cooperatives to which the farmers hold membership and through which they have access to the insurance product shows a

Table 3. Results of the Anderson-Gill cox regression model.

\begin{tabular}{|c|c|c|c|c|c|c|}
\hline & HR & St.Err. & t-value & $p$-value & [95\% Conf] & [Interval] \\
\hline \multicolumn{7}{|l|}{ Gender: (base $=$ Women) } \\
\hline Gender: (base = Men) & 0.989 & 0.046 & -0.24 & 0.81 & 0.903 & 1.083 \\
\hline Prime & 0.999 & $2.81 \mathrm{e}-06$ & -1.11 & 0.267 & 0.999 & 1 \\
\hline \multicolumn{7}{|l|}{ Zone: (base = Kaffrine) } \\
\hline Zone: (base = Koungheul) & 1.047 & 0.115 & 0.42 & 0.676 & 0.845 & 1.297 \\
\hline Zone: (base = Ndoffane) & 1.173 & 0.082 & 2.27 & $0.023^{\star *}$ & 1.022 & 1.346 \\
\hline Zone: (base = Nioro) & 1.055 & 0.069 & 0.82 & 0.412 & 0.928 & 1.2 \\
\hline \multicolumn{7}{|c|}{ Cooperatives: (base $=$ FEPROMAS) } \\
\hline Cooperatives: (base $=$ CCPA) & 1.184 & 0.108 & 1.85 & $0.065^{\star}$ & 0.99 & 1.417 \\
\hline Cooperatives: (base $=$ RNCPS) & 1.299 & 0.09 & 3.80 & $0.000^{* * *}$ & 1.135 & 1.487 \\
\hline \multicolumn{7}{|l|}{ Delayed payment (base = Yes) } \\
\hline Delayed payment $($ base $=$ No) & 0.802 & 0.054 & -3.26 & $0.001^{\star * *}$ & 0.702 & 0.916 \\
\hline \multicolumn{7}{|l|}{ Payout: (base $=$ No) } \\
\hline Payout: (base $=$ Yes) & 3.966 & 0.299 & 18.25 & $0.000^{* * *}$ & 3.42 & 4.598 \\
\hline Mean dependent var & \multicolumn{2}{|c|}{1.991} & \multicolumn{2}{|c|}{ SD dependent var } & \multicolumn{2}{|c|}{0.656} \\
\hline Pseudo r-squared & \multicolumn{2}{|c|}{0.009} & \multicolumn{2}{|c|}{ Number of obs } & \multicolumn{2}{|c|}{3698} \\
\hline Chi-square & \multicolumn{2}{|c|}{415.815} & \multicolumn{2}{|c|}{ Prob $>$ chi $^{2}$} & \multicolumn{2}{|c|}{0.000} \\
\hline Akaikecrit. (AIC) & \multicolumn{2}{|c|}{$45,233.087$} & \multicolumn{2}{|c|}{ Bayesiancrit. (BIC) } & \multicolumn{2}{|c|}{$45,289.027$} \\
\hline
\end{tabular}

Source: Author. $P$-values provide the level of significance of the estimators. There are significance level of $10 \%\left({ }^{*} p<0.10\right)$, significance level of $5 \%\left({ }^{* *} p<0.05\right)$, and significance level for $1 \%\left({ }^{* * *} p<0.01\right)$. 
clear difference between the chances to renew the insurance contracts by the farmers. Farmers of CCPA seem to have 18\% more chance to renew their insurance contracts after the first purchase than farmers of FEPROMAS though the difference is only significant at $10 \%$ level. For RNCPS farmers, the difference is higher and much more significant with more than $29 \%$ chance to renew first-year WII contract compared to farmers of FEPROMAS. These differences could be explained by the importance the leaders of the cooperative give to the insurance product in their priorities and hence the level of efforts the cooperatives make to enroll its members every year in terms of communication and promotion of the insurance product. Our results show that the chances to renew are lower by $20 \%$ for farmers who did not benefit from delayed payment compared to farmers who paid their premium at the moment of the reimbursement of their loans. Regarding the payouts, they provide the highest significant difference in terms of the longevity of the insurance contracts. Farmers who received a payout have a $296 \%$ more chance to renew their contracts than farmers who did not receive a payout.

The results show no significant difference between men and women in the explanation of the renewal of the insurance uptake. The amount of premium paid does not also explain the renewal of purchase. However, cooperatives to whom farmers are affiliated significantly influence the renewal. Farmers of CCPA and RNCPS seem to have more chances to renew their insurance contracts after the first purchase compare to farmers of FEPROMAS. The delayed premiums payment, namely whether the premiums can be pre-financed by the loans and repaid at the end of the production period that the insurance contract covers, has a positive effect on insurance uptake. Chances to renew uptake are also higher for farmers who received payouts compared to farmers who did not.

\section{Conclusion}

In this work, we have estimated the determinants of the renewal of index insurance contracts by Senegalese farmers affiliated to the farmers' organizations FEPROMAS, RNCPS, and CCPA. We used a secondary database provided by the CNAAS containing 3698 observations. Our results showed that the gender of the producers and the amount of the premiums are not significant in the explanation of the renewal of the subscription to the insurance. On the other hand, the cooperative to which the producer is a member and which serves as an aggregator for the distribution of insurance, the delayed premiums payment, namely whether the premiums can be pre-financed by the loans and repaid at the end of the production period that the insurance contracts cover, and finally, the payment of compensation to producers, were the main drivers of the renewal of agricultural insurance contracts between 2014 and 2016 in the groundnut basin of Senegal. Our work thus contributes to the literature by showing that it is above all the aggregators who determine the renewal of contracts and that compensation also plays a major role in the renewal decision of producers and the 
cooperatives to which they belong.

\section{Conflicts of Interest}

The author declares no conflicts of interest regarding the publication of this paper.

\section{References}

Andersen, P. K., \& Gill, R. D. (1982). Cox's Regression Model for Counting Processes: A Large Sample Study. Annals of Statistics, 10, 1100-1120.

https://doi.org/10.1214/aos/1176345976

Banerjee, A., Duflo, E., \& Hornbeck, R. (2014). Bundling Health Insurance and Microfinance in India: There Cannot Be Adverse Selection If There Is No Demand. American Economic Review, 104, 291-297. https://doi.org/10.1257/aer.104.5.291

Cai, H., Chen, Y., Fang, H., \& Zhou, L. (2009). Microinsurance, Trust and Economic Development: Evidence from a Randomized Natural Field Experiment. Working Paper 15396, National Bureau of Economic Research. https://doi.org/10.3386/w15396

Carter, M., de Janvry, A., Sadoulet, E., \& Sarris, A. (2014). Index-Based Weather Insurance for Developing Countries: A Review of Evidence and a Set of Propositions for Up Scaling. Development Policies, Working Paper 111.

Chen, K. Z., Liu, Y., Hill, R., Xiao, C., \& Liu, L. (2012). Can We Relax Liquidity Constraints on Microinsurance Demand? Piloting an Innovative Design for Agricultural Insurance. Technical Report, Microinsurance Innovation Facility, ILO.

Chetaille, A., \& Lagandré, D. (2010). L'assurance indicielle, une réponse face aux risques climatiques? Grain de sel, 49, 20-21.

Cole, S., Gine, X., Tobacman, J., Topalova, P., Townsend, R., \& James, V. (2013). Barriers to Household Risk Management: Evidence from India. American Economic Journal: Applied Economics, 5, 104-135. https://doi.org/10.1257/app.5.1.104

Dandekar, V. M. (1977). Crop Insurance for Developing Countries. Teaching and Research Forum No. 10.

Galarza, F., \& Carter, M. R. (2010). Risk Preferences and Demand for Insurance in Peru: A Field Experiment. 2010 Annual Meeting, Denver, Agricultural and Applied Economics Association, 25-27 July 2010.

Gine, X., \& Yang, D. (2008). Patterns of Rainfall Insurance Participation in Rural India. The World Bank Economic Review, 22, 539-566. https://doi.org/10.1093/wber/lhn015

Gine, X., \& Yang, D. (2009). Insurance Credit and Technology Adoption: Field Experimental Evidence from Malawi. Journal of Development Economics, 1, 1-11. https://doi.org/10.1016/j.jdeveco.2008.09.007

Halcrow, H. G. (1948). The Theory of Crop Insurance. Ph.D. Dissertation.

Karlan, D., Osei, R., Osei-Akoto, I., \& Udry, C. (2014). Agricultural Decisions after Relaxing Credit and Risk Constraints. The Quarterly Journal of Economics, 129, 597-652. https://doi.org/10.1093/qje/qju002

Khalid, M., \& Serieux, J. (2018). Uptake of Voluntary Health Insurance and Its Impact on Health Care Utilization in Ghana. Health Policy and Planning, 33, 861-869. https://doi.org/10.1093/heapol/czy063

Liu, Y., Chen, K., Hill, R., \& Xiao, C. (2013). Borrowing from the Insurer: An Empirical Analysis of Demand and Impact of Insurance in China. IFPRI Discussion Paper. 
https://doi.org/10.2139/ssrn.2373239

Skees, J. R., Barnett, B. J., \& Hartell, J. J. (2006). Innovations in Government Responses to Catastrophic Risk Sharing for Agriculture in Developing Countries (25 p.). Research in Agricultural and Applied Economics.

Stein, D. (2011). Paying Premiums with the Insurer's Money: How Loss Aversion Drives Dynamic Insurance Decisions. Mimeo. 